\title{
GENDERING MADNESS AND DOUBLING DISABILITY IN JANE EYRE
}

\section{LA LOCURA COMO CONSTRUCCIÓN DE GÉNERO Y LA DUPLICACIÓN DE LA DISCAPACIDAD EN JANE EYRE}

\author{
Sunanda Sinha \\ Satyawati College (University of Delhi) \\ sunandasinha@satyawati.du.ac.in
}

\begin{abstract}
Jane Eyre has a well-designed structure of a bildungsroman that focuses on the pursuit of Jane's desire and ignores the same for Bertha. The conceptual structure conveys a linear discourse to determine a prefixed understanding of Bertha, Jane, and Rochester. In Bertha's context, the bildungsroman operates to deliver issues of race, gender, and disability in an existential quest to ascertain and establish her madness. There is a well-designed structural correspondence of bildungsroman, interplay of dark and light binary, the desire of Jane against the asexual Bertha, and the metaphor of fire in mapping the doubling. The literary devices serve as a dominant metaphorical barrier to normalcy in Thornfield. The paper considers this authorial viewpoint on Bertha's sickness as a construct of a parallel gendered and a more potent conceptualisation of madness. In problematising madness, the paper argues a cultural narrative of representation that is affected by the impaired mind of Bertha. It will interrogate how the narrative systematically forges a doubling within which she is objectified, influenced, muted, bounded and characteristically disabled.
\end{abstract}

Keywords: Desire, madness, impaired mind, gender representation, objectification, disability.

\section{Resumen}

Jane Eyre presenta la estructura característica de una bildungsroman que se centra en los deseos de Jane e ignora los de Bertha. Su estructura conceptual contiene un discurso lineal que promueve una concepción predeterminada de Bertha, Jane y Rochester. En el contexto de Bertha, la bildungsroman se centra en las temáticas de raza, género y discapacidad y en el conflicto existencial que determina su locura. Se establece una correspondencia estructural bien diseñada entre la bildungsroman, la oposición binaria entre luz y oscuridad, el deseo de Jane por 
oposición a la Bertha asexual, y la metáfora del fuego para conceptualizar estas dualidades. En el caso de Thornfield, los recursos literarios construyen una barrera metafórica dominante que impide su normalidad. Este artículo analiza el punto de vista de la autora sobre la enfermedad de Bertha como un constructo de género que conlleva una conceptualización más potente de la locura. Al problematizar la locura, este artículo traza la existencia de una narrativa cultural de representación influida por la mente dañada de Bertha. Igualmente, demostrará cómo esta narrativa sistemáticamente la cosifica, la influencia, la enmudece, la limita y la incapacita.

Palabras clave: deseo, locura, mente dañada, representación de género, objetivación, discapacidad.

\section{Introduction}

Bertha's life, when pieced together in the narrative, appears to be built as an apology for the unhappy domestic life of Rochester. The wealthy girl from a Spanish town was popular for her beauty and captured Rochester's attention, who was piqued by both families trying to build their match. Post marriage he confesses his guilt for being an active participant in the lure and willingly surrendering to the temptation. He further adds, "Her relatives encouraged me; competitors piqued me; she allured me: a marriage was achieved almost before I knew where I was. Oh, I have no respect for myself when I think of that act! ... I never loved, I never esteemed, I did not even know her" (Brontë 269). The rest of the telling is Rochester's troubled face-off with lies, deceit, cover-ups, and efforts to restrain violence unleashed by Bertha. The couple returns to England and Bertha is imprisoned in the third-floor room with an attendant, Grace Pool. As the violent insanity progressed, Rochester travels abroad, subverting Bertha's existence, and living a life clouded with mystery. Meanwhile, on different occasions, Bertha manages to start a fire in Rochester's room, bites and stabs her visiting brother, and tears Jane's wedding veil. In the end, we are told Bertha starts a fire that despite Rochester's sincere efforts to save her consumes her, leaving Rochester crippled, partially blind, and free to pursue his romantic interest in Jane.

In the entire narrative of Bertha, Charlotte utilises several 'doublings' to chalk out Victorian morality: antithetically distinguishing the beauty and the beast, the desirable and the disgustful, the spirit and the ghosts, and the capable and disable. Similarly, Bertha is also "Rochester's dark shadow and opposite" (Williams 40) and a double for Jane as well, "she is Jane's alter ego, her demonic, dark side. What we then have is an interesting triadic relationship between Jane, Rochester and Bertha" (Smyth 289). Bertha then, despite being important to the 
plot, is repeatedly constructed through madness against the sane and abled Rochester and Jane. In the comparison too, there is a conscious effort to overlook her medical condition to focus on the objectified, influenced, and justifiably bounded deranged wife. Post the revelation of Bertha's presence in the Attic room too, the genealogy of her sick constitution and absurd nature are the only points of reference in the discussion. Her insufficiency is spelled out and identified to limit her interests, desires, needs, existence. Her existence is demarcated as noncontributing. She never moves to the forefront and there is hardly any normalcy assigned to her even when she is in a stable condition, and discussions are largely around episodes of frantic and violent behaviour. Her marginalisation is at the forefront, foreshadowed by the pursuit of Jane's empowerment in the bildungsroman. Bertha is complicated and yet, familiar in the normative objectification both as a woman and a disabled person. She never gains prominence and all of her representations are aimed and shaped by symbolic antithetical doubling, which Robyn Warhol observes is "the trope of 'doubleness' in [...] women writers" (857). Gilbert and Gubar extend the doubling in the narratives to a peculiar dilemma of the female authors who inadvertently "desire to both accept the strictures of patriarchal society and to reject them" (78) at the same time. They accentuate the potential of the female authors to subconsciously manifest the burden of their anxiety on their characters: "the madwoman in literature by women is not merely, as she might be in male literature, an antagonist or foil to the heroine. Rather, she is usually in some sense the author's double, an image of her own anxiety and rage" (Gilbert and Gubar 78). Thus Bertha's character, while shouldering the burden of Charlotte's angst, is also used to serve the dichotomic function to maximise differences between the visual, spatial, and experiential domains of both women. The next parts of the paper engage with these visual, spatial, and experiential doubling which empowers the binary between the desired Jane and the disgustful Bertha.

\section{Bertha's Bildungsroman or the Lack of Thereof}

In her brief, yet extremely significant presence in Jane Eyre, Bertha's character is narrated by Jane, the omniscient narrator, and constructed by both, Rochester and Jane. There is no effort to integrate her in the main plot and she is restricted to the narrative margins of Jane and Rochester, existing as a facilitator: fulfilling an influencer's motif in their romance. Her plot can be divided into two parts: firstly, the cover-up for her existence and later, the revelation of her uneasy and undesired presence in the third-floor room. Bertha's plot begins when Jane accepts a position of a governess and moves to Thornfield, a few days later she saves Rochester from a fire which she is told was started by a drunken help, Grace Poole. Jane's 
suspicion around this version grows by the presence of Grace in Thornfield even after the negligent drunken episode. As the romantic plot proceeds, the mystery of the episode hangs heavily around the narrative until Bertha makes a physical appearance right before the wedding day of Rochester and Jane. All this while there is a forced absence of her presence: though she is constructed for the readers, she is rendered invisible in the seemingly gothic feel to the mystery surrounding Thornfield. Her invisibility seems to fulfil the tenet that places the text in the Gothic literary tradition and she shoulders the gothic along with Rochester. Gothic tradition flourished on a variety of associations, conjuring together the sublime and the horrible in a mixture "where the classical was well ordered, the Gothic was chaotic; where the classical was simple and pure, Gothic was ornate and convoluted; where the classics offered a world of clear rules and limits, Gothic represented excess and exaggeration, the product of the wild and the uncivilized" (Punter 7). Interestingly, this chaotic, convoluted, exaggerated and uncivilised is centre of all enquiry in the introduction of Bertha. Her problematic mystery is initiated by the very first reference of her, the laugh:

While I paced softly on, the last I expected to hear in so still a region, a laugh, struck my ears. It was a curious laugh-distinct, formal, mirthless. I stopped. The sound ceased, only for an instant. It began again, louder-for at first, though very distinct, it was very low. It passed off in a clamorous peal that seemed to echo in every lonely chamber, though it originated but in one, and I could have pointed out the door whence the accents issued... for the laugh was as tragic, as preternatural a laugh as any I ever heard; and, but that it was high noon, and that no circumstance of ghostliness accompanied the curious cachinnation; but that neither scene nor season favored fear, I should have been superstitiously afraid. (Brontë 92-93)

Her introduction, the laugh, clearly embodies the obscure, abstract, abnormal, and fearful. Jane is visibly moved by this laugh and tries to enquire the source of the hauntingly uneasy voice. Her curiosity begins a chain of lies where the source of the laugh is misplaced by imposing the burden of Bertha's voice and actions on Grace Pool. As if the burden of her existence is already not enough, it is required to be shared and shouldered by another intriguing and enigmatic character, her attendant. All evidence of Bertha is readily attributed to Grace; she then is blamed, chided, monsterised, and criminalised for the acts of Bertha. The underlying mystery surrounding Grace furthers the gothic thread of a nurse attending a 'madwoman' and serves the right purpose of adding up to the intrigue of Bertha. Grace's 'square,' 'staid,' and conservatively dressed middle aged appearance too compliments her purpose in the plot. Unlike Bertha, there is no foregrounding of 
Grace's character and there is bare minimum detailing of her which includes her mirthless and patient demeanour. Apart from these, the only significant detail that stands out is the drinking habit and the resultant carelessness of Grace. Additionally, every time Bertha manages to sneak out and unleash havoc, we are told, Grace's drunken carelessness caused the episode. Grace then, is not just a cover-up for Bertha's existence, her carelessness is also the reason Bertha manages to make her presence felt. Interestingly, if it was not for the drunken carelessness of Grace, maybe, Bertha's character would not exist at all. Both share a symbiotic relationship of coexistence and are tempered by the acts and capacities of each other. Her madness is as essential as is Grace's carelessness for the existence of the two.

The tragic laugh, eccentric murmurs, the unnatural, gurgled moan, progressed to the quarrel between Bertha and her brother "snarling, snatching sound of almost like dogs quarrelling" (Brontë 182). Jane again associates the voices with Grace but Bertha's attack on her brother and his threat to call off the wedding causes Rochester to come out with the truth post the veil episode. The truth slips out only once the wedding had to be cancelled. By the time Jane had a face-off with Bertha's violent behaviour, she is already in a double bind of her relationship, and the genealogy of Bertha's madness is timely served by Rochester to add onto her already horrific experience. As an apology to his marital status, Rochester narrates rather constructs a one-sided version of Bertha's background for Jane. We are told Bertha is from a rich Plantation family of Jamaica, West Indies, and was strikingly beautiful and proud in her younger days. Her family, however, had a genetic history of madness, therefore, her father eagerly fixed her marriage to Rochester and generously gave a dowry of 30,000 pounds. Rochester is initially smitten by the beautifully proud woman but the chink in the armour quickly overshadows the possibility of conjugal bliss:

I found her nature wholly alien to mine, her tastes obnoxious to me, her cast of mind common, low, narrow, and singularly incapable of being led to anything higher, expanded to anything larger... whatever topic I started, immediately received form her a turn at once coarse and trite, perverse and imbecile---when I perceived that I should never have a quiet or settled house-hold, because no servant would bear the continued outbreaks of her violent and unreasonable temper, or the vexations of her absurd, contradictory, exacting orders. (Brontë 270)

Soon after they return to Thornfield, Bertha is confined to the third-floor attic with Grace Poole. The entire telling of Bertha's background is a sort of dramatic monologue by Rochester which, at times, is tempered by Jane's responses in such a manner that it impedes any association of normalcy to Bertha. Jane, at the centre 
of the omniscient narration in this progressive bildungsroman, readily contributes to Bertha's othering: "Jane is poor, plain, little, pale, neat, and quiet, while Bertha is rich, large, florid, sensual and extravagant" (Gilbert and Gubar 361). The visual binary is furthered by Bertha's present disabled state and its history. Both of which are constructed by active memory of Jane and recollections by Rochester. Bertha's disability diverts us from considering her as a person; she is, then, merely a crazy, madwoman never a woman, wife, daughter let alone even remotely a mother. There is a conscious looking away from her and focussing at others to render meaning to her shadowy presence-while we persistently pursue Jane's bildungsroman, we are made to consciously ignore Bertha's. At the end, when John is praised by Jane and reconsidered kindly, no efforts are made to erase Bertha's stigma. She dies with the burden of starting a fire that causes her death and the disability of Rochester, again a destructive force. Another reading of it could be Bertha as the reason for the reversal of situation, the conduit of the relationship but there is an in-betweenness in her telling by others that focuses more on the changed identities of Rochester and Jane, and their Victorian relationship goals. Bertha's bildungsroman is a cliched build-up to madness and certainly, no redemption is offered in her death. Standing big with her long hair against the flaming fire, her final fall on the pavement where she lay "dead as a stone on which brain and blood scattered outside" (Brontë 379) is gory and revolting. Even in death, Bertha's brain is laid bare and paraded for the readers, making a spectacle out of an organ that is at the centre of her disabling. There is a continuous negative perversity around every act, existence, and the death of Bertha. She dies with the burden of disabling Rochester whom we are told tried to save Bertha during the penultimate fire that gutted Thornfield Hall. She falls prey to an objectification of her mental condition where she is viewed only as a destructive force: be it her family, Rochester's life, and her disability, his relationship with Jane, or the final decimation of Thornfield Hall. While Jane advances with blossoming potential in the bildungsroman, Bertha stagnates, declines, deteriorates, and the need for a logical end of the novel necessitates her poetic removal from the narrative.

\section{The Discourse on Darkness and Racial Inequity}

Every character serves a purpose in the story, the real purpose of Bertha seems to be to draw a parallel to the piously plain Jane; an antithesis of all Jane embodies; an arrangement to inevitably empower the binary between the desired and the disgustful. There are complicit structures in the narrative which return time and again to the mad spectacle to reduce Bertha's mind, body, self, and being. There is a conscious bleakness associated with her mixed heredity suggesting her parents 
wanted her to marry Rochester because he was a 'good race.' Her face is dark, discoloured, fearful, and ghastly; her features are savage, she is 'purple' and has 'red eyes' (Brontë 259), she is tall, sturdy and could match Rochester. All this hints towards an innate impurity in Bertha influenced by her heredity and environment. Her physical and natural boundaries are set and informed by this impurity and rallied throughout the novel by association with darkness. While Jane manages to reclaim her space and self, Bertha is confined to darkness and never given the possibility to set herself free from this curse. Helene Cixous, in The Laugh of Medusa, engages with the politics of darkness, "Dark is dangerous...we have internalized this fear of the dark...we the repressed of culture, our lovely mouths gagged with pollen, our wind knocked out of us, we the labyrinths, the ladders, the trampled spaces, the bevies-we are black and we are beautiful" (Cixous 878). There are many interpretative avenues in Jane Eyre which characterise Bertha's being through this repressive darkness, diminishing her character within the male gaze as shadowy, unnatural, dark, and destructive. Jane's narration for the first part is based on hearsay and her own shadowy experience of the sights and sounds that she finds eerily unnatural. Her outsider's position and ambitious background destabilises her objectivity as the reliability of her view is tempered by a potential professional and personal motivation. Readers are also made to accept her subjective point of view which is heightened by the gothic enclosure and unnatural setting. The combination of these two critically charges the tenor of darkness associated with Bertha with the sole claim to create elements of the mad spectacle of darkness.

The other aspect of the narrative surreptitiously similar in its effort to frighten, heavily relies on Rochester's subjective account of the failed marriage, "Bertha Mason is mad; and she came of a mad family; idiots and maniacs through three generations! Her mother, the Creole, was both a madwoman and a drunkard! - as I found out after I had wed the daughter: for they were silent on family secrets before" (Brontë 257). Charlotte intentionally feeds the binary of dark and light, positioning Bertha in dark and Jane in light, and also entitles Rochester with male privilege. Bertha is at the receiving end of this invisible privilege: she has no rights, neither over her body nor mind, she is a site of discursive construction where specific characteristics (dark and dangerous aspects) of disability are part of discussion and she is viewed within the parameters of her infirmities. In between these demonising efforts, she is at the mercy of Rochester and Jane for a few sympathetic words: Jane chastises Rochester's description of Bertha, "You are inexorable for that unfortunate lady: you speak of her with hate-with vindictive antipathy. It is cruel-she cannot help being mad" (Brontë 265). Similarly, Rochester too offers his considerate view on her life, he tells Jane Ferndean would have been too dark and would have killed Bertha, hence she was 
moved to Thornfield. Rachel Ablow, in the context of nineteenth century, asserts in her work The Marriage of Minds: Reading Sympathy in the Victorian Marriage Plot, "sympathy was increasingly identified with the private sphere [...] as a structure through which the subject is constituted in relation to others" (3). Bertha is the object of discussion by Jane and Rochester which is fraught with the traditional representation of the abled and sympathy is used to systematically dehumanise her against the normative conformity. These few sympathetic instances do more to elevate the character of Rochester and Jane than to humanise Bertha. These are then paralleled against the dogmatic attempts to systematically influence Bertha's normalcy and further damage her being. They succeed in her characterisation and are cemented by her nuanced disabling through the dark gothic imagination.

The narrative further sustains and deepens his experience as her experience, rarely addressing Bertha directly. She is the invisible disable, mere disable, inhuman not just ideologically but an intellectual other too. While this othering is significantly executed by Rochester, Jane too shoulders it as a complicit participant. Jane's life experiences are contrasted with the antagonistic existence of Bertha and her face-off with the sounds and sights of Bertha largely determine the 'othering.' It seems Bertha is actualised by both Rochester and Jane's version of her telling which largely rests on formulaic use of colour in Imperial imagination. Jane leads the gothic motive and ascribes darkness in her every effort to understand the sounds and sights of Bertha. There is an unmissable colour-based reading that branches into metaphorical construction of dark and light when Jane comments, "My master's colorless, olive face, square, massive brow, broad and jetty eyebrows, deep eyes, strong features, firm, grim mouth" (Brontë 185). Her attempts to allude no colour to Rochester and 'dark,' 'purple' to Bertha is a part of series of references stereotyping race, ethnicity, and sexuality to dogmatic subjective assumptions. According to Firdous Azim, Bertha is "imagined as white - or as passing white-in the novel's retrospective narrative" (252). The whiteness is later appropriated to black "the form in which she becomes visible in the novel" (252). The racial ambiguity highlighted with the colour-play develops an ambivalence towards Bertha. She is shaped by colour signifiers that enable an uncivil, animalistic racial specificity to her condition. Gayatri Chakravorty Spivak in her essay "Three Women's Texts and a Critique of Imperialism" asserts the novel deliberately engages with an awareness of cultural superiority and broadly endorses Imperial ideology. Spivak notes through "Bertha Mason, The White Jamaican Creole, Charlotte renders the human/animal frontier as acceptably indeterminate, so that a good greater than the law could be broached" (121). These inequities are acquired and expanded to incite fear and the metaphor of darkness, which could also be interpreted as ignorance about her condition, become a marker The Grove. Working Papers on English Studies 28 (2021): 111-126. ISSN: 1137-005X. 
of structural racism. The novel is full of intermittent references to non-white races, a sort of mocking hints of blackness against white supremacy. The discrimination is carried forward with ample instances of racial markers in other characters. $\mathrm{Mr}$. Reed's reference to his mother's 'dark skin' or Lady Ingrams' 'non-white face' furthers the bleakness, ambiguity, darkness, ignorance, and ambivalence which supplements the social and moral stratification based on colonialist racial ideals of the Victorian age.

\section{The Rhetoric of Desire and Bertha}

Chapter 12 of Jane Eyre is a poignant cry for equal treatment and an exposition of woman's desire. For the most of the novel, Jane articulately expresses her sexuality and the need for personal, familial, and social subjectivity in an inclusive gender representation. She challenges the dogmatic conventions, assumptions and does not conform to the Victorian idea of physiognomy:

It is vain to say human beings ought to be satisfied with tranquillity: they must have action; and they will make it if they cannot find it. Millions are condemned to a stiller doom than mine, and millions are in silent revolt against their lot. Nobody knows how many rebellions ferment in the masses of life which people earth. Women are supposed to be very calm generally: but women feel just as men feel; they need exercise for their faculties and a field for their efforts as much as their brothers do; they suffer from too rigid a restraint, too absolute a stagnation, precisely as men would suffer; and it is narrow-minded in their more privileged fellow-creatures to say that they ought to confine themselves to making puddings and knitting stockings, to playing on the piano and embroidering bags. It is thoughtless to condemn them, or laugh at them, if they seek to do more or learn more than custom has pronounced necessary for their sex. (Brontë 95)

In Victorian age the phenomenon of plain heroines also became popular and acquired an empowering stance in the quest for female identity, "physically less beautiful subject at last came into her own [...] the experience of lacking beauty becomes as discursively shareable as any-becomes legible as a human experience" (Mao 4). Jane's plainness is employed to challenge the pervasive notion of superiority and ownership in class and gender paradigm:

Do you think, because I am poor, obscure, plain, and little, I am soulless and heartless? You think wrong!- I have as much soul as you - and full as much heart! And if God had gifted me with some beauty and much 
wealth, I should have made it as hard for you to leave me, as it is now for me to leave you. (Brontë 240)

Interestingly, right after this poignant discourse on a woman's desire and being, we are subjected to conjectures of Jane on the sights and sounds of Bertha that she associates with Grace Pool. Her scrutiny is imprisoned in the strangeness of Grace's character and appearance. On the one hand, Jane voices the most compelling argument in favour of the autonomy of women, on the other, she denies the same scope to Grace and Bertha by categorising them as deviant and strange. The narrative sources each episode of Bertha in which the body becomes a bearer of meaning; its characteristics are laid down as social, political, ethical, and religious signifiers. Though Jane's plainness produces a counter-narrative to the beauty imports of the age, it is also characteristically used as a tool to establish moral codes of Victorian society. Bertha's body, in contrast, is used as a reductionist metaphor to side-line her essential being in favour of her madness. A product of gothic imagination, repressed and fantasized at every opportunity.

Susan Gubar and Sandra Gilbert, in their seminal work The Mad Woman in the Attic, interrogate Charlotte's diffidence towards Bertha "the difficult task of achieving true female literary authority by simultaneously conforming to and subverting patriarchal literary standards" (73). Charlotte naturally assigns agency to Jane which is questionably missing for Bertha, she also parallelly reinforces Bertha's status quo and the perils of the degeneracy of her body and mind. There are marked boundaries between Jane and Bertha: the rebellious feminism attributed to Jane is notably absent for Bertha; a unique odd division with exactly opposite notions of performance, experience, and desire. The paradigmatic binary is furthered by two separate methods used to define 'natural feminine sexuality.' In Jane's hands, it becomes a discourse of radical feminism, whereas for Bertha her sexuality functions violently, destructively, and invokes established paradigms of sexuality of disabled people. The distinguishing attributes of womanhood, sexuality, and motherhood are not formulated for Bertha and the reader is accustomed to and overpowered with her deranged behaviour, and the urgent need to impose confinement on her to prevent any mishappening. Bertha's dependency for normalcy is further associated with her asexual existence; the novel overlooks her womanhood, her need for sex, and her reproductive ability/desire to have children. Fine and Ash in their article "Disability beyond stigma: Social interaction, discrimination, and activism" have discussed how normative femininity is denied to disabled women. Bertha's docile body, the unchanging mute sexual identity with no dynamism or fluidity is the desired body. The impaired mind, a symbol of imperfection, is a medium to usurp the social, economic, sexual, and human rights from her. The complete suppression of 
Bertha's space and power in Thornfield Hall, negates the possibility of a cure for her condition. Hence, that which is not curable is sexually odd, different, and unacceptable. The dominant conservative Victorian culture of healthy female sexuality within the wedded bliss is pitted against the aberrant body and mind of Bertha. Her madness has made her sexless; her desires, needs, and companionship are crushed under her mental state. The mental incapacity becomes an indicator of her disabled needs/non-existent needs. While Jane, with her words and actions, redefines sexuality, Bertha is differentiated and burdened with assumptions on sexuality and the notion of what constitutes familial well-being which, we are often told, rests on her passivity and captivity. The sterile complicity is constructed as ideal and the novel hardly engages with whether Bertha would cherish a family, free life, or a household.

The difference between Bertha and Jane is lengthy and well pronounced; yet, at another level, Jane is made to adhere to the hierarchal underpinning of the novel. She, despite being the new-age cultural, moral, and feminist figure, is viewed by Rochester as the one who fulfills the Victorian stereotype of propriety, "You have the air of a little nonnette; quaint, quiet, grave, and simple, as you sit with your hands before you, and your eyes generally bent at the carpet" (Brontë 181). The in-betweenness about Jane externalises Charlotte's resolve to temper her overt sexuality and defiant attitude with conforming ideals. In the same spirit, the power dynamics between Rochester and Jane fluctuates in a balancing act with a purpose to achieve an equilibrium between the two. Ironically, the patriarchal assertions remain intact for Bertha, who exists only within an unwavering notion of restraint and control. Those few incidences when Bertha is on her own, are spectacles of havoc, disrupting happiness in Thornfield Hall. Another issue is the problematic inference that any interaction of Bertha, human or otherwise, is troublesome. Her level of distress, loneliness, and vulnerability is strengthened by the social isolation imposed on her in the name of safety. Elaine Showalter asserts "much of Bertha's dehumanization, Rochester's account makes clear, is the result of her confinement, not its cause. After ten years of imprisonment, Bertha has become a caged beast" (121). Her physical separation from the common spaces of the house to third-floor attic, tantamount to an admission of an access restriction preventing her from associating with the normal beings and spaces in the house. How could then something as natural as desire, sexuality, and being flourish or even exist in a household of prevention, coercion, and abuse? To put things in a wider perspective, there is a conversion of feelings of companionship and the idea of relationship when it concerns Jane, as Rochester solemnly swears "Every atom of your flesh is as dear to me as my own: in pain and sickness it would still be dear" (Brontë 424). For Rochester to hide Bertha through a despicable living arrangement, and yet, profess his dedication to Jane 'in sickness and health' 
uncovers a discriminatory crisis at the heart of the novel. This crisis, the peculiar singularity of Bertha, is represented through the germs of insanity, disability, and monstrosity as a grotesque double to the autonomous heterogeneity, extensive versatility, and expansive humanity of Jane. From this vantage point, both characters are dialectically opposite in terms of the identity within their gender and sexuality. Bertha's simmering sexuality is associated with insanity and rejected by the Victorian conventional morality that prefers Jane's selfdetermination and subdued passion. Jane's acceptance of a subservient role shorn of excessive passion rewards her with a husband, motherhood, home, and status in convectional Victorian society. Bertha, on the other hand, is cast down and punished for her lurid presence and sexuality by depriving her of social, physical, personal needs, and later, the exorcist spectacle of Thornfield Hall through the fire and violent death of Bertha.

\section{Conclusion}

The fire motif in Jane Eyre is critically crucial to the psychological reduction of Bertha. At a first glance, it is used to prolong the hopeless, dreary gothic shadow over her characterisation; on a deeper look, it resonates with her situation and forms an uncanny double. This double is a part of several other doublings in the novel that serve to strengthen the othering. Bertha as the repressed double to Jane in the equation of the divine and the devil, suitably fulfils the role of the truest and darkest double. According to Gilbert and Gubar, "Bertha has functioned as Jane's dark double throughout the governess's stay at Thornfield. Specifically, every one of Bertha's appearances - or, more accurately, her manifestations - has been associated with an experience (or repression) of anger on Jane's part" (360). Jane's supressed anger, in this context, is the explosive fire within Bertha that finds externalisation in many episodes she manages to set fire in Thornfield. The metaphor of fire introduces the impediment, and according to Rey Chow, "in terms of plot structure, the fire removes the impediment, the madwoman" (145). After the first fire, which also marks the presence of Bertha, there is a change in the demeanour of Rochester, who becomes "desperate and brooding" (Brontë 412). This episode marks the beginning of many such occasions of Fire as the silent background to interactions between Rochester and Jane; the mute backdrop of a simmering intimacy. On the other side of the wall, Bertha's madness is simmering in the same propensity. The presence of fire in the absence of Bertha, the presence of fire and Bertha together, and the penultimate torching of Thornfield Hall that consumes Bertha and cripples Rochester resonates with the symbolic lifegenerating and destructing power of fire. Bertha too destroys, purifies, and generates life through the unsettling chaos she introduces in Rochester's life that 
leads to the new beginning for both Jane and him. Bertha dies in the fire she begins; Rochester is crippled by the fire she sets. She jumps to her death and also pulls down the Thornfield Hall structure: the fire resonates with the destruction of the space she was confined to. The symbolic fall of the building is breaking free from the barriers of the walls and the intent behind the structure of the master what Laura Donaldson asserts is "an act of resistance not only to her status as a woman in a patriarchal culture but also as a colonized object" (76). Fire changes the equation between Jane and Rochester and establishes a sort of equality between the two. Bertha is responsible for Rochester's disability and the dilution of Jane's spirit. Her absence (death) sets in motion a boundary for both Rochester and Jane where both are sighted and tied together in limited possibility, a sort of castration of their dreams. Bertha's removal from the narrative coincides with the disturbing dampening of Jane's feminist spirit, a sort of what is made to appear a natural compromise to settle for disabled Rochester. All of his sins are purged by the fire and pave the way to let Jane reconsider their union as a legitimate closure of their relationship. This fire and its consequences also change Jane's view of St. John from a cold-hearted and repressed to a philanthropic soul and yet, nothing changes for Bertha. Judith Butler in the context of illegal, illegitimate subjects writes, "a life that is not supposed to be grieved is also a life that is not supposed to have existed at all" (Pizzo 45). In this context, the suppression of Bertha's individuality, unlike Jane who gets to act out her contradictions and tensions in her vivid experience of growth, is akin to the illegitimate subjects under surveillance ("politically silenced subject", Berlant 10), who never get to express or exercise self-hood. The beginning of Bertha in the novel then is also the beginning of her end, for she is never fully formed and goes unrecognised within the bureaucracy of the abled body. The end of Bertha also renders Jane as a marker of sane, fulfilling, earnestly devoted nurturer; fixed in a conventionally linear role. The demise of Bertha, consequently the end of all antithetical doubling, also ends the straight-jacketed approach of Jane and removes her from the doubling equation to place her as a more acceptable, nurturing, and forgiving Victorian woman.

\section{WORKS CITED}

Ablow, Rachel. The Marriage of Minds: Reading Sympathy in the Victorian Marriage Plot. Stanford UP, 2007.

Azim, Firdous. The Colonial Rise of the Novel. Routledge, 1993.

Berlant, Lauren Gail. Compassion: The Culture and Politics of an Emotion. Routledge, 2004.

The Grove. Working Papers on English Studies 28 (2021): 111-126. ISSN: 1137-005X. 
Brontë, Charlotte. Jane Eyre. 1847. Ed. Novy Kapadia. Worldview Publications, 2016.

Chow, Rey. "When Whiteness Feminizes: Some Consequences of a Supplementary Logic." Differences: A Journal of Feminist Cultural Studies, vol. 11, no. 3, 1999, pp. 137-68. https://doi.org/10.1215/10407391-11-3-137

Cixous, Helene, Keith Cohen, and Paula Cohen. "The Laugh of the Medusa." Signs: Journal of Women in Culture and Society, vol. 1, no. 4, 1976, pp. 875-93. https://doi.org/10.1086/493306

Donaldson, Laura E. "The Miranda Complex: Colonialism and the Question of Feminist Reading." Diacritics vol. 18, no. 2, 1988, pp. 65-77. https://doi.org/10.2307/465255

Fine M., \& A. Ash. "Disability Beyond Stigma: Social Interaction, Discrimination, and Activism." Journal of Social Issues, vol. 44, no. 11, 1988, pp. 3-21. https://doi.org/10.1111/j.1540-4560.1988.tb02045.x

Gilbert Sandra M., and Susan Gubar. The Madwoman in the Attic: The Woman Writer and the Nineteenth-Century Literary Imagination. Yale UP, 1979.

Mao, Douglas. "The Labor Theory of Beauty: Aesthetic Justice, Blind Justice." Aesthetic Subjects. Eds. Pamela R. Matthews and David McWhirter. University of Minnesota Press, 2003, pp. 190-229.

Pizzo, Justine. Charlotte Brontë, Embodiment and the Material World. Springer Nature Switzerland AG, 2021. https://doi.org/10.1007/978-3-030-34855$\underline{7}$

Punter, David, and Glennis Byron. The Gothic. Blackwell Publishing, 2004.

Showalter, Elaine. A Literature of Their Own. Princeton UP, 1977.

Smyth, Donna E. Metaphors of Madness: Women and Mental Illness. Mount Saint $\begin{array}{llll}\text { Vincent } & \text { University, } & 6 & \text { Aug. }\end{array}$ https://journals.msvu.ca/index.php/atlantis/article/download/4762/3992/ 6205 Accessed 10 Dec. 2021.

Spivak, Gayatri. A Critique of Postcolonial Reason. Harvard UP, 1999. https://doi.org/10.2307/j.ctvjsf541

Warhol, Robyn. "Double Gender, Double Genre in Jane Eyre and Villette." SEL, vol. 36, no. 4, 1996, pp. 857-75. https://doi.org/10.2307/450979

Williams, Judith. Perceptions and Expressions in the Novels of Charlotte Brontë. University of Rochester Press, 1988. 
Received September 212021

Revised version accepted December 192021 
